\title{
TINGKAT KESEJAHTERAAN RUMAH TANGGA PETANI MENURUT TIPOLOGI MASYARAKAT
}

\author{
Tity Iriani Datau ${ }^{\star}$ 1), Syarwani Canon ${ }^{2)}$, Amir Halid ${ }^{3)}$ \\ 1) Badan Perencanaan Pembangunan Daerah Provinsi Gorontalo \\ 2) Fakultas Ekonomi Universitas Negeri Gorontalo \\ 3) Fakultas Pertanian Universitas Negeri Gorontalo \\ *) Corresponding Author E-mail: tyrianidatau@gmail.com
}

\begin{abstract}
ABSTRAK
Upaya peningkatan kesejahteraan khususnya petani di pedesaan terus dilakukan oleh pemerintah dengan mengembangkan Kawasan Pertanian Terpadu. Penelitian ini bertujuan unutuk menganalisis tingkat pendapatan dan alokasi pengeluaran, dan tingkat kesejahteraan rumah tangga petani padi sawah di Kecamatan Wonosari Kabupaten Boalemo. Data yang digunakan dalam penelitian ini adalah data cross section dari 88 petani dari keseluruhan tipologi petani yang menempati Kawasan Pertanian Terpadu Kecamatan Wonosari Kabupaten Boalemo. Tehnik analisis data menggunakan tehnik analisis deskriptif terhadap tingkat pendapatan dan alokasi pengeluaran, dan perhitungan rasio daya beli rumah tangga petani (DBPP) dan nilai tukar pendapatan rumah tangga petani (NTPRP) sebagai tolok ukur tingkat kesejahteraan petani. Hasil penelitian menunjukkan bahwa pendapatan dari usahatani padi sawah dan usahatani lainnya lebih besar dibanding pendapatan non-pertanian dari ketiga tipologi petani baik petani lokal, petani non-lokal dan petani campuran. Rata-rata tingkat daya beli petani dari ketiga tipologi petani berkisar antara $2,14-6,70$, sedangkan rata-rata nilai NTPRP adalah lebih besar dari satu $(>1)$ dan berkisar antara 1,38 - 8,66. Pengembangan Kecamatan Wonosari sebagai Kawasan Pertanian Terpadu menjadikan para petani sejahtera secara ekonomi.
\end{abstract}

Kata kunci: Pendapatan; Kesejahteraan; Petani; Kawasan Pertanian Terpadu

\section{PENDAHULUAN}

Segala upaya pemerintah dalam pembangunan pada berbagai sektor yang telah dilakukan berhasil membawa kemajuan pada berbagai aspek kehidupan masyarakat. Namun, dibalik keberhasilan tersebut masih terdapat beberapa permasalahan mendasar, yaitu kemiskinan, pengangguran, dan ketimpangan. Berbagai ketimpangan terjadi antara satu sektor dengan sektor lainnya, antara wilayah satu dengan wilayah lainnya, maupun antar pelaku ekonomi. Ketimpangan antar wilayah kemudian menjadi terminologi daerah tertinggal, yakni daerah yang relatif kurang menunjukkan perkembangan dibandingkan daerah lain.

Berdasarkan data BPS 2016, persentase penduduk miskin Kabupaten/Kota seProvinsi Gorontalo kondisi maret 2016 sebanyak 17,63 persen dari total penduduk Provinsi Gorontalo 1.150.765 jiwa. Ini menunjukkan bahwa kondisi kemiskinan di Provinsi Gorontalo khususnya di Kabupaten/Kota masih cukup tinggi dibanding rata-rata nasional yang mencapai 10,86 persen. Untuk itu perlu adanya upaya-upaya yang dilakukan oleh pemerintah pusat dan pemerintah daerah dalam rangka mencari solusi bagi permasalahan kemiskinan khusunya ditingkat petani melalui program ekonomi kerakyatan yang diharapkan tidak saja dapat meningkatkan kesejahteraan masyarakat tetapi sebagai solusi bagi masyarakat agar terus mandiri, mempunyai jiwa entrepreneur dalam memecahkan masalah-masalah yang berkaitan dengan pembangunan di daerahnya. 
Kawasan pertanian terpadu di Kabupaten Boalemo yang berbasis kecamatan ditetapkan pemerintah Provinsi Gorontalo berlokasi di Kecamatan Wonosari. Masyarakat yang telah menetap di Kecamatan Wonosari sebagian besar bekerja sebagai petani dengan komposisi masyarakat yang terbagi dalam tiga tipologi masyarakat yaitu mayarakat lokal yang merupakan masyarakat suku gorontalo yang secara turun temurun berdomisili di Kecamatan Wonosari. Kedua tipologi masyarakat non-lokal yaitu masyarakat dari luar suku Gorontalo yang datang sebagai peserta program transmigrasi dan oleh pemerintah di tempatkan di Kecamatan Wonosari. Dan yang ketiga tipologi masyarakat campuran yang merupakan hasil perkawinan antara masyarakat lokal asli gorontalo dengan pendatang yang berasal dari berbagai suku yang datang dan tinggal di Kecamatan Wonosari.

Survei angkatan kerja nasional (Sakernas) tahun 2015 menunjukkan bahwa pertanian masih merupakan sektor andalan bagi penduduk Kabupaten Boalemo karena sekitar 59,26 persen penduduknya bekerja pada sektor ini. Namun demikian, jumlah penduduk miskin pada tahun 2016 berjumlah 32.290 jiwa atau 21,11 persen, jumlah ini mengalami peningkatan dibandingkan penduduk miskin pada 2015 yang berjumlah 32.190.

Upaya peningkatan kesejahteraan khususnya petani di pedesaan seharusnya terus berlanjut. Untuk itu perlu terus adanya intervensi program dan kegiatan pemerintah yang intensif dengan alokasi anggaran yang memadai dengan tujuan untuk pengentasan kemiskinan khususnya program-program yang dialokasikan ke kecamatan/desa salah satunya dengan upaya pengembangan Kawasan Pertanian Terpadu yang telah dilaksanakan oleh pemerintah provinsi sejak tahun 2015 melalui Keputusan Gubernur Gorontalo Nomor 96/20/III/2015 tanggal 2 maret 2015 tentang Penetapan Lokasi dan Pembentukan Kelompok Kerja Pengembangan Kawasan Pertanian Terpadu Provinsi Gorontalo. Dengan berkembangnya kesempatan kerja dan kesempatan berusaha masyarakat perdesaan merupakan alternatif kegiatan dan sumber pendapatan masyarakat persedaan terutama untuk petani yang memiliki lahan sempit dan petani tanpa lahan. Besarnya peran sektor pertanian sebagai pendapatan rumah tangga merupakan akumulasi peran antar subsektor, terutama tanaman pangan dan hortikultura yang mempunyai peran sangat besar dalam pendapatan rumah tangga disamping diversivikasi pendapatan dari subsektor perkebunan, peternakan, kehutanan, maupun usaha non pertanian. Selain itu struktur pengeluaran rumah tangga dipengaruhi oeleh beberapa hal diantaranya perubahan pengeluaran menurut waktu, perbedaan antar selera, perbedaan pendapatan dan lingkungan. Perilaku pengeluaran rumah tangga yang tersedia harus sesuai dengan tingkat kemampuan pendapatan yang diperoleh dan bagaimana mendistribusikannya, agar tidak terguncang untuk memenuhi kebutuhan dibawah tingkat kesejahteraan. Akses kebutuhan rumah tangga terhadap pengeluaran bahan pangan dan bukan bahan makanan yang dibutuhkan sangat tergantung dari daya beli, tingkat pendapatan, harga pangan, proses distribusi, kelembagaan tingkat lokal maupun kondisi sosial lainnya.

\section{METODE}

Jenis penelitian ini merupakan jenis penelitian kuantitatif yang menggunakan data yang bersumber langsung dari petani berupa pendapatan dan pengeluaran dari berbagai sumber kebutuhan rumah tangga petani. Penelitian ini dilakukan di Kabupaten Boalemo yaitu pada Kecamatan Wonosari dimana penetapan lokasi ditetapkan secara sengaja (purposive) karena sesuai Keputusan Gubernur Gorontalo Nomor 96/20/II/2015 tanggal 2 maret 2015 tentang Penetapan Lokasi dan Pembentukan Kelompok Kerja Pengembangan Kawasan Pertanian Terpadu Provinsi Gorontalo Tahun 2015.

Data yang digunakan dalam penelitian ini adalah data cross section dari 88 petani dari keseluruhan tipologi petani yang menempati Kawasan Pertanian Terpadu Kecamatan Wonosari Kabupaten Boalemo yaitu tipologi petani lokal, petani non-lokal, dan petani campuran. 
Tehnik analisis data menggunakan tehnik analisis deskriptif terhadap tingkat pendapatan dan alokasi pengeluaran, dan perhitungan rasio daya beli rumah tangga petani (DBPP) dan nilai tukar pendapatan rumah tangga petani (NTPRP). Secara matematis pendapatan dari tipologi petani dapat dihitung dengan menggunakan rumus sebagai berikut:

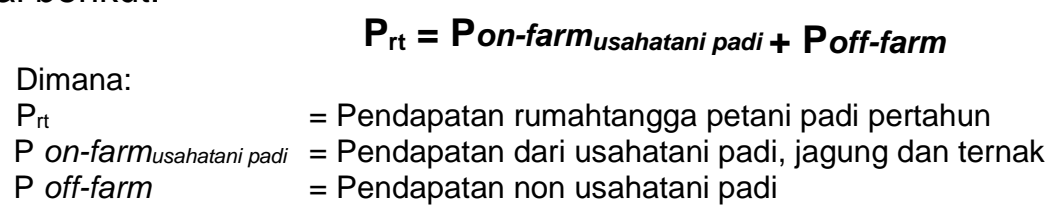

Pengeluaran rumah tangga petani ditentukan dengan rumus sebagai berikut:

Dimana:

$$
\mathbf{P}=\mathbf{S}+\mathbf{K}_{\mathbf{t}}
$$

$\mathrm{K}_{\mathrm{t}} \quad=\mathrm{K}_{1}+\mathrm{K}_{2}$

$\mathrm{P} \quad=$ Pengeluaran

$\mathrm{S} \quad=$ Saving/tabungan

$\mathrm{K}_{\mathrm{t}} \quad=$ Pengeluaran Total

$\mathrm{K}_{1}=$ Pengeluaran untuk makanan

$\mathrm{K}_{2}=$ Pengeluaran untuk non makanan

Kesejahteraan petani diukur dengan rasio daya beli rumah tangga petani (DBPP) dan nilai tukar pendapatan rumah tangg petani (NTPRP). Tehnik perhitungan nilai DBPP dan NTPRP masing-masing adalah sebagai berikut:

$$
\text { DBPP = TP / (TE }- \text { BU) }
$$
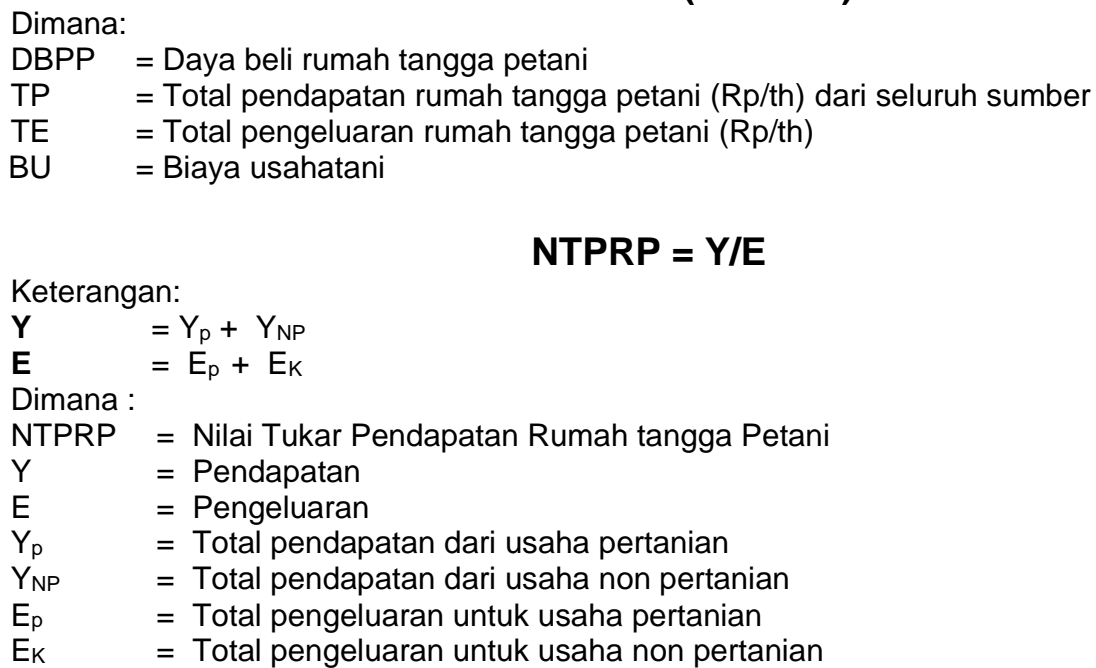

\section{HASIL DAN PEMBAHASAN}

\section{Karakteristik Responden}

Usia responden didominasi oleh kategori usia produktif. Mulai dari usia diatas 20 tahun sampai dengan diatas 50 tahun, sebanyak $51,14 \%$ responden dari berbagai tipologi berusia 41-50 tahun. Usia tersebut tergolong cukup produktif menghasilkan pendapatan dari usahatani. Selanjutnya $30,68 \%$ responden dari ketiga tipologi petani dalam kategori usia sangat produktif. Dari total responden, $\pm 84 \%$ tergolong dalam kategori produktif (berada dalam masa kerja), dan sisanya $16 \%$ dari ketiga tipologi petani telah memasuki masa kurang produktif lagi.

Tingkat pendidikan responden sebagian besar pendidikannya hanya sampai tingkat SD dan SMP dan hanya sebagian kecil sampai pada tingkat SMA dan Perguruan Tinggi (D3/S1). Tingkat pendidikan responden didominasi tingkat SD yakni $43,18 \%$, sedangkan tingkat Diploma (D3) / Sarjana (S1) hanya 1,14\%. 
Jumlah anggota rumah tangga petani responden paling banyak yakni $61,36 \%$ berkisar dari 4-6 anggota rumah tangga, sedangkan sisanya 39,64\% responden memiliki 1-3 jumlah anggota dalam rumah tangga. Semakin banyak jumlah anggota rumah tangga, tentu dapat memperbesar jumlah alokasi pengeluaran dari pendapatan yang diperoleh dalam keluarga, sehingga responden dituntut tidak hanya berpenghasilan dari berusahatani, akan tetapi juga diharapkan bisa memperoleh pendapatan dari usaha pertanian lainnya maupun usaha non-pertanian.

\section{Produksi Padi dan Produktivitas Petani}

Banyaknya produksi padi yang dapat dihasilkan petani sangat ditentukan dari luas panennya. Luas panen dari tanaman padi juga ditentukan dari luas tanamnya. Semakin besar luas tanam maka semakin besar luas panen dan semakin tinggi pula tingkat produksinya. Dari tahun ketahun, total luas panen tanaman padi di Kecamatan Wonosari cenderung menglami peningkatan yang signifikan. Dalam kurun waktu sembilan tahun, masyarakat petani di Kecamatan Wonosari dapat terus meningkatkan luas panennya hingga 68,87\% dari tahun 2009-2017.

Tabel 1 Produksi Padi dan Produktivitas Petani di Kecamatan Wonosari Tahun 2009-2017

\begin{tabular}{ccccc}
\hline No. & Tahun & $\begin{array}{c}\text { Luas Panen } \\
\text { (Ha) }\end{array}$ & $\begin{array}{c}\text { Produksi } \\
\text { (Ton) }\end{array}$ & $\begin{array}{c}\text { Produktivitas } \\
\text { (Kw/Ha) }\end{array}$ \\
\hline 1 & 2009 & 4.424 & 21.108 & 47,71 \\
2 & 2010 & 4.235 & 22.454 & 53,02 \\
3 & 2011 & 4.545 & 24.448 & 53,79 \\
4 & 2012 & 5.167 & $26.858,2$ & 51,98 \\
5 & 2013 & 5.543 & $31.226,8$ & 56,34 \\
6 & 2014 & 5.969 & $33.564,9$ & 56,23 \\
7 & 2015 & 5.382 & $29.894,9$ & 55,55 \\
8 & 2016 & 5.973 & $26.001,8$ & 43,53 \\
9 & 2017 & 7.471 & $33.284,6$ & 44,55 \\
\hline \multicolumn{5}{c}{ Rata-Rata } \\
\hline
\end{tabular}

Sumber: BPS Kab. Boalemo, diolah 2018

Tabel 1 menunjukkan produksi padi yang terus meningkat dari tahun ketahun. Pada tahun 2009-2014, produksi padi mencapai 21.108 ton hingga mencapai 33.564,9 ton yakni rata-rata meningkat sebesar $59,02 \%$. Tahun $2015-2017$ pun terjadi peningkatan rata-rata $11,3 \%$ meskipun ditahun 2015 sempat menurun $10,93 \%$ dari tahun sebelumnya. Data produktivitas petani pun menunjukkan angka yang positif, bahwa rata-rata setiap tahun terjadi peningkatan produktivitas. Rata-rata produktivitas petani di Kecamatan Wonosari dapat mencapai $51,41 \mathrm{kwintal} / \mathrm{hektar}$ area setiap tahunnya dan melebihi ratarata produktivitas keseluruhan petani kabupaten. Produktivitas tertinggi petani di Kecamatan Wonosari dapat mencapai 56,34 kwintal/hektar area yakni terjadi ditahun 2013, dan tingkat produktivitas terendah mencapai 43,53 kwintal/hektar area terjadi ditahun 2016.

\section{Pendapatan Rumah Tangga Petani}

Struktur pendapatan rumah tangga petani responden dari ketiga tipologi masyarakat petani di Kecamatan Wonosari dibagi menjadi dua yaitu kelompok pendapatan disektor pertanian dan non-pertanian. Sumber pendapatan disektor pertanian adalah merupakan kontribusi dari pendapatan usaha pertanian yakni usahatani padi sawah dan non padi sawah (seperti palawija dan holtikultura, perkebunan sayur, budidaya ikan dan peternakan) dan diluar usaha pertanian seperti berburuh tani. Sedangkan pendapatan di luar pertanian terdiri dari usaha non-pertanian yang dilakukan oleh kelompok masyarakat petani di Kecamatan Wonosari seperti berdagang, industri pengolahan, kerajinan, jasa transportasi, pegawai, buruh nonpertanian dan pendapatan dari sumber lain seperti penyewaan aset dan lainnya. 
Dari Tabel 2, menunjukkan di Kecamatan Wonosari dari ketiga tipologi masyarakat petani responden, rata-rata total pendapatan rumah tangga terendah adalah pada masyarakat lokal (Rp 63.285 ribu/tahun) dan tertinggi pada masyarakat non-lokal (Rp 116.192 ribu/tahun). Rendahnya pendapatan dari petani lokal, karena pendapatan yang bergantung pada usaha pertanian, terutama usahatani padi mengalami gangguan kekeringan yang mengakibatkan produksi padi relatif rendah. Didalam struktur pendapatan rumah tangga petani responden, secara keseluruhan dari ketiga tipologi masyarakat petani yang terbesar adalah pendapatan dari sektor pertanian yakni $83,5 \%$ dibanding sektor non-pertanian yang hanya $16,5 \%$. Secara parsial, porsi pendapatan dari sektor pertanian di Kecamatan Wonosari oleh petani lokal (Rp. 1.585 .050 ribu/tahun) relatif lebih rendah dibanding petani non-lokal (Rp. 2.958 .850 ribu/tahun) dan petani campuran (Rp. 2.577.100 ribu/tahun). Hal ini menunjukkan bahwa pendapatan dari ketiga tipologi petani, disektor pertanian lebih didominasi oleh petani non-lokal dan petani campuran. Besarnya pendapatan di sektor pertanian oleh petani non-lokal, berasal dari kontribusi pendapatan usaha pertanian seperti usaha padi sawah, palawija serta kegiatan berburuh tani. Berbeda halnya dengan tipologi petani campuran, kontribusi pendapatan pertanian berasal dari usahatani dengan berbagai komoditas seperti jagung, dan perkebunan sayur disamping pendapatan buruh tani dan ternak. Sementara itu, besarnya kontribusi pendapatan di sektor pertanian terhadap total pendapatan rumah tangga petani padi sawah masih relatif sama antara tipologi masyarakat petani responden, yaitu ratarata berkisar antara $80 \%-86 \%$.

Tabel 2. Rata-Rata Pendapatan Rumah Tangga Petani Berdasarkan Tipologi Masyarakat Petani Di Kecamatan Wonosari

\begin{tabular}{|c|c|c|c|c|c|c|}
\hline \multirow{2}{*}{ No. } & \multirow{2}{*}{\multicolumn{2}{|c|}{$\begin{array}{c}\text { Sumber } \\
\text { Pendapatan }\end{array}$}} & \multicolumn{3}{|c|}{ Tipologi Masyarakat Petani } & \multirow{2}{*}{$\begin{array}{c}\text { Rata-Rata } \\
\text { / Petani } \\
\text { (Rp. 000) }\end{array}$} \\
\hline & & & Lokal & Non-Lokal & Campuran & \\
\hline \multirow[t]{3}{*}{1} & $\begin{array}{l}\text { On-farm } \\
\text { (Rp. 000) }\end{array}$ & $\begin{array}{l}\text { Usahatani } \\
\text { Padi Sawah }\end{array}$ & 1.414 .350 & 2.522 .050 & 2.356 .100 & 23.835 \\
\hline & & $\begin{array}{l}\text { Usahatani } \\
\text { lainnya }\end{array}$ & 170.700 & 436.800 & 221.000 & 3.138 \\
\hline & & Jumlah & 1.585 .050 & 2.958 .850 & 2.577 .100 & \\
\hline \multirow[t]{3}{*}{2} & $\begin{array}{l}\text { Non-farm } \\
\text { (Rp. 000) }\end{array}$ & & 313.500 & 759.300 & 419.100 & 5.651 \\
\hline & \multicolumn{2}{|c|}{ Total } & 1.898 .550 & 3.718 .150 & 2.996 .200 & \\
\hline & \multicolumn{2}{|c|}{ Rata-Rata } & 63.285 & 116.192 & 115.239 & \\
\hline
\end{tabular}

Sumber: Data primer diolah, 2018

\section{Alokasi Pengeluaran Rumah Tangga Petani}

Pengeluaran rumah tangga petani responden dikelompokkan menjadi dua bagian, yaitu pengeluaran untuk usaha pertanian dan pengeluaran untuk bukan usaha pertanian (non-pertanian). Struktur pengeluaran rumah tangga dipengaruhi oleh besar kecilnya usaha pertanian yakni terdiri dari biaya tetap maupun biaya variabel, perubahan pengeluaran menurut waktu, perbedaan selera, perbedaan pendapatan dan lingkungan. Sehingga alokasi pengeluaran baik dari masyarakat petani lokal, petani non-lokal, dan petani campuran untuk usaha pertanian maupun non-pertanian ini hampir berbeda.

Tabel 3 menunjukan bahwa nilai total pengeluaran petani responden di Kecamatan Wonosari dari ketiga tipologi masyarakat petani sangat bervariasi, mulai dari alokasi untuk usaha pertanian padi sawah, usaha tani lainnya (non-padi sawah), dan juga alokasi pengeluaran untuk kebutuhan rumah tangga petani. Dari ketiga tipologi masyarakat petani, rata-rata total nilai pengeluaran untuk usaha pertanian baik untuk usahatani padi sawah dan usahatani lainnya, bahwa petani non-lokal (Rp. 60.001 ribu/tahun) lebih besar 
dibandingkan kelompok petani lokal (Rp. 45.847 ribu/tahun) dan petani campuran (Rp. 49.975 ribu/tahun). Namun demikian bila dilihat proporsi pengeluaran rumah tangga petani dari rata-rata per petani secara keseluruhan untuk biaya usaha pertanian (Rp. 14.315 ribu/tahun) masih lebih kecil dibandingkan rata-rata konsumsi pangan per petani (Rp. 18.669 ribu/tahun) dan rata-rata konsumsi non-pangan per petani (Rp. 16.288 ribu/tahun). Untuk semua kelompok rumah tangga petani lebih banyak didominasi oleh pengeluaran yang bersumber dari konsumsi pangan (padi-padian (beras dan non beras), umbi-umbian, ikan, daging, telur dan susu, sayur-sayuran, buah-buahan dan bahan makanan dan minuman dan lain-lain seperti teh, kopi dan gula serta tembakau) dan konsumsi non-pangan (kebutuhan harian rumah tangga, biaya pendidikan, biaya kesehatan, dan lain-lain). Sebanyak 31\% - 38\% alokasi pengeluaran terserap untuk konsumsi pangan dan non-pangan dari seluruh total pengeluaran rumah tangga. Hal ini menunjukan bahwa rumah tangga petani dari masing-masing tipologi petani berorientasi untuk menyeimbangkan konsumsi makanan dan non makanan sesuai dengan tingkat kebutuhannya. Demikian pula untuk kebutuhan usaha pertanian, sebanyak 26\% - 29\% baik dari petani lokal, non-lokal dan campuran terserap untuk usaha pertanian khususnya untuk usaha tani padi sawah tersebut.

Tabel 3 Rata-Rata Alokasi Pengeluaran Rumah Tangga Petani Berdasarkan Tipologi Masyarakat Petani Di Kecamatan Wonosari

\begin{tabular}{|c|c|c|c|c|c|c|}
\hline \multirow{2}{*}{ No } & \multirow{2}{*}{\multicolumn{2}{|c|}{ Jenis Biaya }} & \multicolumn{3}{|c|}{ Tipologi Masyarakat Petani } & \multirow{2}{*}{$\begin{array}{c}\text { Rata-Rata / } \\
\text { Petani } \\
\text { (Rp. 000) }\end{array}$} \\
\hline & & & Lokal & Non-Lokal & Campuran & \\
\hline 1 & $\begin{array}{l}\text { On-farm } \\
\text { (Rp. 000) }\end{array}$ & $\begin{array}{l}\text { Usahatani } \\
\text { Padi Sawah }\end{array}$ & 338.580 & 494.837 & 309.900 & 12.890 \\
\hline \multirow{4}{*}{2} & \multirow{4}{*}{$\begin{array}{l}\text { Non-farm } \\
\text { (Rp. 000) }\end{array}$} & $\begin{array}{l}\text { Usahatani } \\
\text { lainnya }\end{array}$ & 30.000 & 60.350 & 36.150 & 1.425 \\
\hline & & $\begin{array}{l}\text { Konsumsi } \\
\text { Pangan }\end{array}$ & 515.226 & 654.516 & 477.840 & 18.669 \\
\hline & & $\begin{array}{l}\text { Konsumsi } \\
\text { Non-Pangan }\end{array}$ & 429.208 & 609.261 & 403.452 & 16.288 \\
\hline & & Saving & 62.400 & 101.060 & 72.000 & 2.669 \\
\hline \multicolumn{3}{|c|}{ Jumlah } & 1.375 .414 & 1.920 .024 & 1.299 .342 & \\
\hline \multicolumn{3}{|c|}{ Rata-Rata } & 45.847 & 60.001 & 49.975 & \\
\hline
\end{tabular}

Sumber: Data primer diolah, 2018

Sementara itu pengeluaran untuk saving (tabungan) dari ketiga tipologi petani, ratarata berkisar antara $4 \%-6 \%$ dari total pendapatan yang dihasilkan dari usaha pertanian maupun non-pertanian. Saving dilakukan oleh para petani untuk kebutuhan yang telah terencana dimasa mendatang seperti kebutuhan investasi usaha, kebutuhan biaya pendidikan anggota keluarga, juga berjaga-jaga dari kebutuhan yang bersifat mendesak (dadakan) baik untuk usaha pertanian dan konsumsi rumah tangga petani.

\section{Analisis Daya Beli Rumah Tangga Petani (DBPP)}

Daya beli rumah tangga petani merupakan salah satu indikator kesejahteraan ekonomi petani. Analisis daya beli rumah tangga petani (DBPP) diperoleh dari hasil bagi total pendapatan dengan total pengeluaran rumah tangga selain biaya usahatani. Dari hasil ini dapat dilihat tingkat kemampuan/daya beli rumah tangga petani terhadap kebutuhan konsumsi pangan. Semakin tinggi tingkat daya beli petani, maka semakin baik juga akses petani untuk mendapatkan kebutuhan pangan, sehingga tingkat ketahanan pangan keluarga manjadi lebih baik. Dengan demikian, semakin tinggi tingkat daya beli rumah tangga, berarti tingkat kesejahteraan keluarga petani yang bersangkutan semakin tinggi, dan begitu juga sebaliknya, semakin rendah tingkat daya beli rumah tangga petani, maka semakin rendah pula tingkat kesejahteraan keluarga petani yang bersangkutan. 
Tabel 4 Tingkat Daya Beli Rumah Tangga Petani (DBPP) Berdasarkan Tipologi Masyarakat Petani Di Kecamatan Wonosari

\begin{tabular}{|c|c|c|c|c|c|c|}
\hline \multirow{3}{*}{ DBPP } & \multicolumn{6}{|c|}{ Tipologi Masyarakat Petani } \\
\hline & \multicolumn{2}{|c|}{ Lokal } & \multicolumn{2}{|c|}{ Non-Lokal } & \multicolumn{2}{|c|}{ Campuran } \\
\hline & $\begin{array}{l}\text { Jumlah } \\
\text { (Orang) }\end{array}$ & Nilai & $\begin{array}{l}\text { Jumlah } \\
\text { (Orang) }\end{array}$ & Nilai & $\begin{array}{l}\text { Jumlah } \\
\text { (Orang) }\end{array}$ & Nilai \\
\hline Maksimum & 15 & 17,88 & 21 & 12,55 & 8 & 45,6 \\
\hline $\begin{array}{l}\text { Minimum } \\
\text { Rata-rata }\end{array}$ & 15 & $\begin{array}{c}-27,17 \\
2.17\end{array}$ & 11 & $\begin{array}{c}-23,77 \\
\mathbf{2 , 1 4}\end{array}$ & 18 & $\begin{array}{l}0,71 \\
6.70\end{array}$ \\
\hline
\end{tabular}

Sumber: Data diolah, 2018

Tabel 4 menunjukkan bahwa daya beli rumah tangga petani responden lebih besar dari $1(>1)$ artinya pendapatan petani lebih besar dari pengeluaran yang dikeluarkan ratarata petani. Rata-rata daya beli rumah tangga petani pada tipologi petani campuran $(6,70)$ masih lebih tinggi dibandingkan dengan daya beli petani lokal $(2,17)$ dan non-lokal $(2,14)$. Hasil tersebut membuktikan bahwa para petani tipologi campuran lebih mampu memenuhi kebutuhan akan konsumsi pangannya meskipun semua tipologi petani tergolong dalam kategori petani sejahtera. Akan tetapi dari ketiga tipologi masyarakat petani di Kecamatan Wonosari, masih juga terdapat beberapa petani dari tipologi lokal, non-lokal maupun campuran yang belum mampu memenuhi kebutuhan akan pangan. Terbukti bahwa tingkat nilai DBPP untuk petani lokal $(-27,17)$ dan non-lokal $(-23,77)$ berada pada angka minus dan petani campuran $(0,71)$ berada pada angka kurang dari 1 $(<1)$. Dari hasil tersebut, pada tipologi masyarakat petani lokal dan non-lokal ada beberapa kelompok rumah tangga petani yang sangat rendah daya belinya, bahkan dapat dikatakan belum mampu memenuhi kebutuhan akan pangannya. Oleh karenanya, kelompok tersebut perlu diperhatikan oleh pemerintah setempat, sehingga petani-petani dapat memenuhi kebutuhan rumah tangga dari hasil usahanya, serta tingkat kesejahteraannya dapat meningkat.

\section{Analisis Nilai Tukar Pendapatan Rumah Tangga Petani (NTPRP) Sebagai Tolok Ukur Tingkat Kesejahteraan Rumah Tangga Petani}

Nilai tukar pendapatan rumah tangga petani (NTPRP) adalah penanda tingkat kesehteraan yang merupakan nisbah antara pendapatan dan pengeluaran, sehingga dapat terukur besarnya tingkat kesejahteraan petani selama melakukan aktivitasnya. Pada Tabel 5, memperlihatkan NTPRP terhadap total pengeluaran baik itu pada tipologi masyarakat petani lokal, non-lokal dan campuran yang bervariasi. NTPRP tipologi masyarakat petani lokal, non-lokal dan campuran di kecamatan wonosari rata-rata lebih besar dari satu (NTPRP, mulai dari 1,38-8,66). Hal ini berarti bahwa rumah tangga petani tersebut telah menunjukan tingkat kesejahteraannya. Keadaan ini disebabkan karena besarnya total pengeluaran baik biaya untuk usaha pertanian maupun non-pertanian khususnya konsumsi (pangan dan non pangan) tidak melebihi besarnya total pendapatan sebagai komponen pembentukan NTPRP.

Besarnya NTPRP dari masing-masing tipologi masyarakat petani terhadap total konsumsi nilainya lebih kecil (NTPRP $=2,0-3,4)$ dibanding nilai NTPRP terhadap total biaya produksi (NTPRP $=5,15-8,66$ ). Keadaan ini menunjukkan bahwa untuk memenuhi tingkat kesejahteraan rumah tangga petani dari ketiga tipologi masyarakat petani di Kecamatan Wonosari relatif lebih banyak mengalokasikan pendapatannya untuk memenuhi kebutuhan konsumsi dibanding kebutuhan usahanya. Namun demikian diantara pengeluaran untuk kansumsi baik pangan dan non-pangan, besarnya NTPRP relatif seimbang. Hal ini berarti bahwa sebagian besar rumah tangga petani tersebut berusaha menyeimbangkan besarnya pengeluaran dari kedua komponen konsumsi terhadap besarnya pendapatan yang mereka peroleh. 
Tabel 5 Nilai Tukar Pendapatan Rumah Tangga Petani (NTPRP) Berdasarkan Tipologi Masyarakat Petani Di Kecamatan Wonosari

\begin{tabular}{|c|c|c|c|c|}
\hline \multirow[b]{2}{*}{ No. } & \multirow[b]{2}{*}{ Uraian } & \multicolumn{3}{|c|}{ Tipologi Masyarakat Petani } \\
\hline & & $\begin{array}{c}\text { Lokal } \\
\text { (Rp. 000) }\end{array}$ & $\begin{array}{l}\text { Non-Lokal } \\
\text { (Rp. 000) }\end{array}$ & $\begin{array}{l}\text { Campuran } \\
\text { (Rp. 000) }\end{array}$ \\
\hline A. & Pendapatan & $1,898,550$ & $3,718,150$ & $2,996,200$ \\
\hline 1. & Pendapatan Pertanian & $1,585,050$ & $2,958,850$ & $2,577,100$ \\
\hline a. & Usaha Pertanian & $1,414,350$ & $2,522,050$ & $2,356,100$ \\
\hline b. & Berburuh Tani & 170,700 & 436,800 & 221,000 \\
\hline 2. & Pendapatan Non-Pertanian & 313,500 & 759,300 & 419,100 \\
\hline B. & Pengeluaran & $1,375,414$ & $1,920,024$ & $1,299,342$ \\
\hline 1. & Biaya Produksi Pertanian & 368,580 & 555,187 & 346,050 \\
\hline 2. & Konsumsi Rumah Tangga & 944,434 & $1,263,777$ & 881,292 \\
\hline a. & Pangan & 515,226 & 654,516 & 477,840 \\
\hline b. & Non-Pangan & 429,208 & 609,261 & 403,452 \\
\hline 3. & Saving & 62.400 & 101.060 & 72.000 \\
\hline C. & Nilai Tukar Pendapatan & & & \\
\hline a. & Terhadap Total Pengeluaran & 1.38 & 1.94 & 2.31 \\
\hline b. & Terhadap Biaya Produksi & 5.15 & 6.70 & 8.66 \\
\hline c. & Terhadap Konsumsi Pangan & 3.68 & 5.68 & 6.27 \\
\hline d. & $\begin{array}{l}\text { Terhadap Konsumsi Non- } \\
\text { Pangan }\end{array}$ & 4.42 & 6.10 & 7.43 \\
\hline e. & Terhadap Total Konsumsi & 2.01 & 2.94 & 3.40 \\
\hline
\end{tabular}

Sumber: Data diolah, 2018

\section{SIMPULAN}

Aspek pendapatan rumah tangga dari ketiga tipologi petani baik petani lokal, petani non-lokal dan petani campuran, pendapatan di sektor pertanian adalah yang terbesar yaitu dari usahatani padi sawah dan usahatani lainnya dibanding pendapatan nonpertanian. Hal ini dapat berarti bahwa sebagian besar rumah tangga petani untuk memperoleh pendapatan masih berorientasi pada usaha pertanian sebagai sumber mata pencaharian utama. Akan tetapi, jika dilihat dari aspek pengeluaran, bahwa pengeluaran rumah tangga untuk pangan dan non-pangan masih lebih besar dibanding pengeluaran untuk pembiayaan usahatani. Konsumsi pangan baik untuk kebutuhan bahan makanan dan minuman masih mendapat porsi yang lebih besar diantara alokasi anggaran pengeluaran rumah tangga petani.

Pada ketiga tipologi masyarakat petani baik lokal, petani non-lokal dan petani campuran rata-rata daya beli rumah tangga petani (DBPP) mencapai 2,14 - 6,70. Rasio DBPP diatas satu membuktikan bahwa para petani dari ketiga tipologi mampu memenuhi kebutuhan akan konsumsi pangannya, dan semua tipologi petani tergolong dalam kategori petani sejahtera.

Nilai tukar rumah tangga petani (NTPRP) dari ketiga tipologi petani rata-rata lebih besar dari satu (NTPRP $=1,38-8,66$ ). Hal ini dapat berarti bahwa rumah tangga petani dari ketiga tipologi masyarakat petani tersebut telah menunjukan tingkat kesejahteraannya. Keadaan ini disebabkan karena besarnya total pengeluaran baik biaya untuk usaha pertanian maupun non-pertanian khususnya konsumsi (pangan dan non pangan) tidak melebihi besarnya total pendapatan sebagai komponen pembentukan NTPRP.

\section{DAFTAR PUSTAKA}

Anonim. 2017. Rancangan Akhir RPJMD Provinsi Gorontalo 2017-2022. Bapppeda Provinsi Gorontalo 
Asa Alfrida, Trisna Insan Noor. 2017. Analisis Pendapatan dan Tingkat Kesejahteraan Rumah Tangga Petani Berdasarkan Luas Lahan Sawah. Jurnal. Program Studi Agribisnis Fakultas Pertanian Universitas Padjajaran. Bandung

Badan Pusat Statistik. 2016. Gorontalo Dalam Angka. Gorontalo.

Badan Pusat Statistik. 2013. Sensus Ekonomi 2013. Gorontalo.

Badan Pusat Statistik. 2018. Nilai Tukar Petani 2017. Gorontalo.

BPS Kabupaten Boalemo. 2016. Boalemo Dalam Angka. Boalemo.

Balai Pengkajian Teknologi Pertanian Provinsi Gorontalo, 2014, Rancang Bangun Kawasan Pertanian Terpadu, kerjasama BPTP dan Bappeda Provinsi Gorontalo

Bappenas. 2000. Program Pembangunan Nasional Penanggulangan Kemiskinan. Makalah Diskusi Rakor-Pokja Operasional Gerakan Terpadu Pengentasan Kemiskinan Tk. Pusat. 13 Juni 2000. Jakarta.

BKKBN. 1992. Undang-Undang Republik Indonesia Nomor 10 Tahun 1992 tentang Perkembanga Kependudukan dan Pembangunan Keluarga Sejahtera. Badan Koordinasi Keluarga Berencana Nasional.

Dunham, Arthur. 1991. Organisasi Kesejahteraan Masyarakat (Prinsip dan Praktek). Thomas Y. Crowel Company. New York.

Friedlander, A. Walter. 1991. Introduction to Social Walfare. New Jersey, United State.

Friedman Lee S. 2002 hal. 171. The Microeconomics of Public Policy Analysis. United State.

Handewi P.S. Rahman dan Supriyati. 2005. Struktur dan Distribusi Pendapatan Rumahtangga Petani Lahan Sawah di Jawa dan Luar Jawa. Jurnal. Puslitbang Sosial Ekonomi Pertanian. Bogor.

Mei Tri Sugesti, Zainal Abidin, Umi Kalsum. 2015. Analisis Pendapatan dan Pengeluaran Rumah Tangga Petani Padi Desa Sukajawa, Kecamatan Bumiratu Nuban, Kabupaten Lampung Tengah. Jurnal. Jurusan Agribisnis, Fakultas Pertanian, Universitas Lampung. Lampung.

Mubyarto. (2002). Membangkitkan Ekonomi Kerakyatan Melalui Gerakan Koperasi 'Peran Perguruan Tinggi'. Jurnal. Universitas Gajah Mada. Jogjakarta

Muhamad Nur Wibowo, Endang Siti Rahayu, Sri Marwanti. 2013. Struktur dan Distribusi Pendapatan Rumah Tangga serta Strategi Kebijakan Peningkatan Kesejahteraan Petani Jagung di Lahan Perhutani di Kecamatan Tunggungharjo Kabupaten Grobogan Provinsi Jawa Tengah. Tesis. Program Pascasarjana Universitas Sebelas Maret Surakarta.

Rambe, A. 2004. Alokasi Pengeluaran Rumah Tangga dan Tingkat Kesejahteraan (Kasus di Kecamatan Medan, Kota Sumatra Utara). Tesis. Sekolah Pascasarjana IPB, Bogor

Simatupang P. dan Maulana. 2007. Kaji Ulang Konsep Nilai Tukar Petani Tahun 20032006. Makalah Seminar pada Pusat Analisis dan Kebijakan Pertanian. Oktober 2006. Bogor.

Soeharjo, A dan D. Patong. 1973. Sendi-sendi Pokok IImu Usahatani. Bogor.Institut Pertanian Bogor.

Soekartawi. 1988. Prinsip Dasar Komunikasi Pertanian. Jakarta: Universitas Indonesia. 
Sugiarto. 2008. Analisis Tingkat Kesejahteraan Petani melalui Pola Pendapatan dan Pengeluaran di Pedesaan. Jurnal. Pusat Analisis Sosial Ekonomi dan Kebijakan Pertanian. Bogor.

Suprapti Supardi. 2012. Analisis Ekonomi Rumah Tanggga Tani di Daerah Aliran Sungai (DAS) Solo Hulu Kabupaten Wonogiri. Jurnal. Program Studi Agribisnis Fakultas Pertanian Universitas Sebelas Maret. Solo. 